\title{
Review of Who Owns the Stock? Collective and Multiple Property Rights in Animals edited by Anatoly M. Khazanov and Günther Schlee
}

\author{
Richard Tapper
}

\section{Book details \\ 342 pages, 8 maps, 19 tables, 66 figures, bibliography, index, ISBN 978-0-85745-335-8 Hb, \$95.00/£60.00, elSBN 978-0-85745-336-5}

Keywords: Livestock; Property relations; Russian northeast; Siberia; North China; Mongolia; Kazakhstan; Burkina Faso; Cameroon; Ghana; East Africa

Ancestors such as Daryll Forde and Robert Paine long ago encouraged students of pastoralism to analyse the three-way relation between people, pastures and livestock. Most anthropological studies have inevitably focused on the social organisation of the people. Ecologists and others have examined the relation between livestock and pastures: carrying capacity and overgrazing, migration and migration patterns, animal yields and so on.

The question of people-pasture relations, i.e. rights of access, was long ignored because of a largely unquestioned assumption that such rights were extensive and communal. I questioned this at the 1975 Paris colloquium on Pastoral Production and Society (Équipe 1979) on the basis of my studies of Shahsevan nomads in Iran and Durrani in Afghanistan, and a key collection in Mobility and Territoriality (Casimir and Rao 1992) has since tackled the issue comparatively. Clearly, there is a very wide range of practices; in certain pastoral conditions, individuated rights of access, rental and purchase do develop and flourish, but in most cases, different forms of communal, collective, seasonal/successional rights of access are the rule.

As for the people-livestock relation, there is much detailed ethnographic information available, but again it has taken a while to tackle the issue comparatively. This new collection documents some of the complexity, in different

Correspondence: rt3@soas.ac.uk

The University of London, London, UK forms, of systems of property rights in livestock, examines the responses of these systems in recent times to state and other external pressures and makes some attempt to correlate property regimes with these pressures and other internal factors.

The chapters are all based on recent field research on Chukchi (Patty A. Gray), Dolgan (Aimar Ventsel), Nenets (Florian Stammler) in the Russian northeast, Tozhu and Tofa of South Siberia (Brian Donohoe); Yakut in China (Hugh Beach), Kazakhs in Kazakhstan (Anatoly M. Khazanov) and Mongolia (Peter Finke); Fulbe of Burkina Faso (Youssouf Diallo), northern (Mark Moritz) and north west (Michaela Pelican) Cameroon, and northern Ghana (Steve Tonah). In a final chapter, Günther Schlee compares a number of East African pastoral peoples.

There is no Preface, and the editors' Introduction gives no indication of the origin of the book. It is only on page 250, in Schlee's concluding chapter, that the reader learns that the collection originated in 2002 at a workshop at the Max Planck Institute in Halle, where Schlee is Co-director. Two substantial paragraphs on that page, one occupying a footnote, together with another footnote on page 255, would have served well as a Preface or Foreword.

All the chapters except the Introduction were presented as papers at that workshop. The absence of editorial direction or supervision is noticeable: apparently no common template was either set or enforced. The chapters vary widely in style and content; some appear to 
have been updated; only a few cross-refer to any of the others. There is some repetition, both within and between chapters. A subeditor should have corrected numerous infelicities in the English. Maps are needed in all twelve chapters, but only six have them, and one of them is missing a scale. Most chapters contain tables and figures or (in one case and poorly reproduced) photographs. Some chapters use sketches of reindeer, cattle or camels to show fur marks, ear marks and brands: one chapter (Schlee) devotes an Appendix of no less than 23 pages to 46 sketches of camel brands - nicely drawn, but it is hard to see to what purpose in a collection of this nature. Usefully, we have footnotes not endnotes, but unfortunately the bibliographies are amalgamated into one at the end.

The stuff of discussion throughout the book is the nature of 'ownership'. We find some detailed ethnographic instances and some interesting and on the whole congruent analyses of the components of this concept in practice among a range of different pastoral societies. We are also told, particularly in the north Asian examples, how major changes in the state (to socialism then to post-socialism) differentially affected, sometimes radically, herders' property regimes and indeed their economic well-being. We read sad stories of how collectivization virtually destroyed pastoralism - but also of how herders often found ways around state policies. Then, the collapse of the socialist state led to rushed privatisation, usually resulting in the enrichment of the few and further impoverishment of the many.

Conceptualization, analysis and comparison are impeded by the usual problems with English terminology. For example, most contributors use the terms 'ownership' and 'possession' synonymously; sometimes they are distinguished, though it is not clear how. 'Property' evokes the classic notion of 'bundle of rights'; the editors also insist that property relations are social relations, though they sometimes shorten this to just property, remarking that it is 'generally accepted in the social sciences that property is a relationship between people about denying or allowing each other the use of things' (p. 13): a rather odd notion of property, surely. Several contributors extend this to social relations between people and animals, not just between people; and reindeer herders, particularly, consider the animals to own themselves, as 'autonomous agents who make decisions as to whom they will give themselves' (ibid.).

Several chapters argue for subtle distinctions between 'state' and 'collective', and between 'individual' and 'personal' and 'private' property in livestock and land. Rights in animals cannot be discussed separately from rights in land and often rights in the crops and creatures living on that land. All the chapters devote space to discussion of land rights (ownership/disposal, usufruct), sometimes more than they do to rights in livestock.
While pasturelands usually regenerate after poor seasons, livestock are notoriously vulnerable to climatic vicissitudes and other threats that can in extreme cases annihilate whole herds. Consequently, pastoral societies everywhere have developed mechanisms to insure against and/or spread these risks: multiple and collective forms of ownership, various kinds of loans and obligations of communal aid to the stricken. In these chapters, we read of many of these mechanisms - and how they have been affected, usually adversely, by outside pressures (government changes, marketization and privatisation, and 'Islamic renewal' in the African cases) that have led to greater individualization of property rights, and have not always been replaced by outside aid to alleviate stock disasters.

I should disclose my bias as reviewer. As a student in the 1960s, I read some of the now classic studies of East and West African cattle and camel pastoralists and North Asian reindeer pastoralists, but I am not familiar with the recent work on these regions - represented in this book. On the other hand, the contributors to the book appear to have little or no familiarity with pastoralists in the vast region that is more familiar to me and within which I have done fieldwork: the mixed (mainly sheep and goat) pastoralists of mountainous southwest Asia (Turkey, Iran, Afghanistan) and the camel and small stock pastoralists of the Mediterranean, North Africa and the Middle East.

The editors tell us in the Introduction that 'smallstock [sic] (sheep and goats) are not affected as a rule' (p. 2) by complex, multiple and overlapping property relations. This may be true of the pastoral societies in sub-Saharan Africa and north and Central Asia represented in this book. However, the editors (and the other contributors) appear to rely for their information regarding southwest Asian and Mediterranean small stock nomads on old comparative studies by Dahl and Hjort (1976) and Ingold (1980), neither of which mentions much more than Fredrik Barth's study of the Basseri (Barth 1961). They ignore the wide range of other studies published since and before - that show the Basseri to be far from typical of this vast region. I can assure the editors that their exclusion of this form of pastoralism by the generalisation that '[s]mallstock are disposed of in a straightforward manner. There are no shared rights in individual ewes or she-goats\#x2019; (p. 2) is unwarranted.

Later in the Introduction, the pastoralists of the 'Eurasian steppes and the Middle East' do reappear; the existence of multiple rights in stock is acknowledged, but societies are dismissed as 'much less egalitarian', with multiple rights in livestock 'less conspicuous' than among African pastoralists. One differentiating factor, we learn, is the anticipatory inheritance of stock given to sons on marriage. This is the case with the Basseri and appears 
also to be the case with the Kazakhs described by Khazanov in his chapter - but he rashly claims this to be 'a pattern common to all nomads of the Eurasian steppes' (p. 141). If the latter includes nomads of Iran and Afghanistan other than the Basseri, such as the Shahsevan and the Durrani that I studied myself, it is not the case: paternal and fraternal joint households, with sons not commonly becoming independent 'owners' of stock until their father's death, were common.

In another chapter, Florian Stammler, referring to both Ingold and Barth's study of the Basseri, writes of the 'social isolation' of both their camps and their households, as well as of 'the minor social significance of animals' (pp. 68, 73). Again, a wider reading of the literature on pastoralists of the region would, I think, show the Basseri to be exceptional in all these respects.

Despite these limitations, this volume is a useful compilation of case studies of an important issue for pastoralist studies and should stimulate further relevant research.

\section{Competing interests}

The author declares that he has no competing interests.

\section{Author's information}

Richard Tapper is Emeritus Professor of Anthropology in the University of London.

Received: 10 July 2013 Accepted: 12 July 2013

Published: 1 November 2013

\section{References}

Barth, F. 1961. Nomads of South Persia. Oslo: Oslo University Press. Casimir, MJ, and A Rao (eds.). 1992. Mobility and territoriality. London: Berg. Dahl, G, and A Hjort. 1976. Having herds. Stockholm: University of Stockholm. Équipe écologie et anthropologie des sociétés pastorales (ed.). 1979. Pastoral production and society. Cambridge: Cambridge University Press/Maison des Sciences de l'Homme.

Ingold, T. 1980. Hunters, pastoralists and ranchers. Cambridge: Cambridge University Press.

doi:10.1186/2041-7136-3-21

Cite this article as: Tapper: Review of Who Owns the Stock? Collective and Multiple Property Rights in Animals edited by Anatoly M. Khazanov and Günther Schlee. Pastoralism: Research, Policy and Practice 2013 3:21.

\section{Submit your manuscript to a SpringerOpen ${ }^{\odot}$ journal and benefit from:}

- Convenient online submission

Rigorous peer review

- Immediate publication on acceptance

- Open access: articles freely available online

- High visibility within the field

- Retaining the copyright to your article

Submit your next manuscript at $>$ springeropen.com 